\title{
Uma etnografia da comunidade Chinesa na cidade de São Gonçalo, Rio de Janeiro
}

\author{
Edivan de Azevedo Silva da Costa ${ }^{1}$
}

\begin{abstract}
Resumo: A pesquisa da qual resulta este artigo deriva do aprofundamento das minhas investigações ao longo de seis anos sobre a imigração chinesa no estado do Rio de Janeiro, nas quais busco analisar a comunidade chinesa. O presente trabalho, através das Ciências Sociais, teve como objetivo compreender as redes migratórias e comerciais na região metropolitana do Rio de Janeiro dando destaque a cidade de São Gonçalo. Foram realizadas pesquisas bibliográficas, documentais e etnográficas e a principal conclusão foi que os imigrantes chineses na cidade de São Gonçalo relacionam-se com diversos outros grupos da diáspora chinesa e pensam na sua imigração como temporária.
\end{abstract}

Palavras-chave: Imigração Chinesa. Redes Migratórias. China.

\section{An ethnography of the Chinese community in the city of São Gonçalo, Rio de Janeiro}

\begin{abstract}
The research that results from this article derives from the deepening of my investigations over six years on Chinese immigration in the state of Rio de Janeiro, in which I seek to analyze the Chinese community. The present work, through the Social Sciences, aimed to understand the migratory and commercial networks in the metropolitan area of Rio de Janeiro highlighting the city of São Gonçalo. Bibliographical, documentary and ethnographic research was carried out and the
\end{abstract}

${ }^{1}$ Doutorando no Programa de Pós-Graduação em Ciências Sociais (PPGCS) / Linha de Pesquisa: "Estudo das Relações Brasil-China" da Universidade Estadual de Campinas (UNICAMP). Graduado em Licenciatura Plena em Geografia pela Universidade do Estado do Rio de Janeiro (UERJ) (2014). É mestre em Ciências Sociais, área de concentração: Antropologia Social pela Universidade Federal Rural do Rio de Janeiro (UFRRJ) (2018). E-mail: costa. edivan5@gmail.com 
Uma etnografia da comunidade chinesa...

main conclusion was that Chinese immigrants in the city of São Gonçalo are related to several other groups in the Chinese diaspora and think of their immigration as temporary.

Keywords: Chinese Immigration. Migration Networks. China.

\section{Una etnografía de la comunidad China en la ciudad de São Gonçalo, Río de Janeiro}

Resumen: La investigación de la que resulta este artículo deriva de la profundización de mis investigaciones a lo largo de seis años sobre la inmigración china en el estado de Río de Janeiro, en las que busco analizar la comunidad china. El presente trabajo, a través de las Ciencias Sociales, tuvo como objetivo comprender las redes migratorias y comerciales en la región metropolitana de Río de Janeiro dando destaque a la ciudad de São Gonçalo. Se realizaron investigaciones bibliográficas, documentales y etnográficas y la principal conclusión fue que los inmigrantes chinos en la ciudad de São Gonçalo se relacionan con diversos otros grupos de la diáspora china y piensan en su inmigración como temporal.

Palabras clave: Inmigración Chino. Redes Migratorias. China.

Este artigo será dedicado ao resultado da(s) pesquisa(s) de campo que foram realizadas na cidade de São Gonçalo com o objetivo de entender e analisar a constituição das redes migratórias de chineses no leste metropolitano fluminense. Também, por meio da etnografia, entrevista aberta e observação participante - ferramenta da etnografia - compreender as sociabilidades e os processos identitários de chineses naquele território. Nesse momento, o diário de campo como ferramenta de trabalho dos antropólogos e também de outros cientistas sociais foi uma peça fundamental para o registro de ideias, notas e observações de pertinência para desenvolvimento da pesquisa. Além disso, foi feito um breve levantamento bibliográfico e discussão teórica entre autores de trabalhos dedicados às mobilidades chinesas. Os estudos em campo foram realizados entre abril de 2016 e novembro de 2017 com observação e entrevistas com colaboradores do grupo étnico chinês.

No decorrer da pesquisa percebi que os depoentes chineses tinham receio de identificarem-se com seus nomes. Alguns 
preferiram não mencionarem os nomes, alguns pediram para que suas identidades não fossem reveladas na pesquisa e outros optaram por se identificarem por nomes popularmente brasileiros para que não fossem reconhecidos. Assim, os nomes que aparecem na dissertação são fictícios em respeito aos pedidos de preservação das identidades dos depoentes.

\section{2 - Etnografia e o diário de campo}

Minha retomada ao campo ocorreu como participante da Primeira Mostra de Kung Fu e Cultura Chinesa ${ }^{2}$, que teve participação de grupos de kung fu da cidade e também de chineses. $\mathrm{O}$ evento teve baixa participação de espectadores e pequena presença de chineses. Assim, a mostra de Kung Fu foi mais um enaltecimento por parte dos organizadores do que apresentação da cultura chinesa. Ao longo dos dias percebi a pouca participação de chineses residentes em São Gonçalo na plateia. Os chineses não tiveram espaço para fala e estiveram em segundo plano. Meses após a Primeira Mostra de Kung Fu e Cultura Chinesa através de minha participação no campo, foi relatado pelos depoentes que aquele evento não representou a China, sua cultura e os chineses em São Gonçalo. De acordo com eles, a Mostra se ateve à exibição da arte marcial Kung Fu.

Não gostei daquilo [Primeira Mostra de Kung Fu e Cultura Chinesa] não estava nos representando. Eu não tinha interesse sobre aquilo. Achei bom trabalhar. Achar que chineses só sabem Kung Fu é como falar que vocês [brasileiros] só sambam. (Yi, chinês, aproximadamente 25 anos) $)^{3}$

\footnotetext{
${ }^{2}$ Ocorreu entre os dias 27 de novembro a 06 de dezembro de 2016 na Casa de Villa Real organizado pela Prefeitura Municipal de São Gonçalo.

${ }^{3}$ Depoimento obtido no dia 30 de janeiro de 2017 por um chinês após as comemorações do Ano Novo Chinês em São Gonçalo.
} 
Durante o evento reencontrei com dois chineses: Ena e Yi, que conheci em minha pesquisa monográfica. Eles me apresentaram a outros chineses que tinham chegado ao Brasil nos meses anteriores. Através das conversas consegui estabelecer contato que proporcionou maior inserção no grupo chinês de São Gonçalo. Expliquei que voltara a estudar a China e suas migrações no estado do Rio de Janeiro. Percebi que Ena ficou entusiasmada com minha pesquisa e disse Eu converso de novo (Ena, filha de chineses, 28 anos), todavia, Yi ficou desconfiado do motivo pelo que eu queria compreender a imigração chinesa. Durante minha pesquisa de monografia percebi que Ena não tinha muitos amigos fora da comunidade chinesa e, por ser a gerente da lanchonete de sua família, o trabalho a mantinha ocupada por muito tempo, o que de certo modo a impedia de ampliar sua rede social fora do ambiente familiar e conterrâneo. Ela era muito esperta e hábil, conhecia a comunidade chinesa em São Gonçalo e chineses em outras cidades da região metropolitana fluminense. Dessa maneira, ela passou a ser minha referência para minha inserção no campo. Diante dessas condições, eu era visto como o amigo brasileiro ${ }^{4}$ que afinal havia procurado a aproximação com ela.

Passei a ir uma vez por semana na lanchonete que Ena trabalha no Centro de São Gonçalo para observar as interações entre os chineses com os brasileiros e conversar sobre as experiências dela no Brasil, mas acabávamos conversando sobre outros assuntos do interesse dela - músicas, filmes, novelas e séries de televisão. Algumas vezes, ela comentava que tinha ido para China visitar os tios e que sentia falta do país. Ela não gostava de comentar sobre essa viagem devido às brigas de família.

Ena disse que haveria uma pequena comemoração do Ano Novo Chinês nos dias 28 e 29 de janeiro de 2017 e que já estava convidada. Percebi que aquele evento poderia ser importante em minha pesquisa por estarem presentes chineses que eu

\footnotetext{
${ }^{4}$ Mesmo sendo considerado amigo por ela, eu precisava consumir algo em sua lanchonete para que pudesse ficar sentado nas cadeiras e, quando ela tinha disponibilidade, conversava comigo.
} 
poderia analisar em relação às suas sociabilidades em grupo e performances. Até aquele momento, eu não tinha conhecimento que os chineses se reuniam em São Gonçalo para comemorações do Ano Novo Chinês. Manifestei meu interesse na possibilidade de ir, ela disse que eu não estaria autorizado participar, mas deixou que eu a acompanhasse até a festa que aconteceria no bairro do Alcântara, São Gonçalo.

Encontramo-nos na Praça Zé Garoto e fomos juntos de ônibus até ao Alcântara. Quando estávamos no ônibus, Ena disse que durante a comemoração do Ano Novo é costume que os chineses viajem para suas cidades na China para passar os dias das comemorações com familiares. [O Ano Novo] é quando eles [chineses] voltam para China visitar os parentes e mostrar os filhos nasceram e que ainda não tinha sido conhecido pela família. Nessa época você não falará com eles porque não estão aqui (Ena, filha de chineses, 28 anos). No trajeto da viagem, olhei pela janela e fui percebendo que várias lanchonetes e lojas de chineses estavam fechadas 5 . Durante toda a viagem ela comentava sobre o desejo de quando morrer fosse enterrada na China, pois não queria ser enterrada no Brasil. Ela dizia: Sou até brasileira no documento, mas sou muito mais chinesa (Ena, filha de chineses, 28 anos). Questionei o interesse em ir para China para viver por lá e, ao indagar sobre o intuito da imigração dela e dos outros chineses, me referindo ao projeto de conseguir dinheiro trabalhando no Brasil, voltar para China e trocar o $h u k o u^{6}$ para viver em uma cidade, ela foi enfática.

\footnotetext{
${ }^{5}$ No período de comemorações no Ano Novo Chinês que ocorreu nos anos de 2017 e 2018 observei que estabelecimentos de proprietários chineses estiveram fechados. Além disso, através de depoimentos soube que os chineses viajam para China para participar com familiares das comemorações do Ano Novo.

${ }^{6}$ Registro de residência que pode ser familiar ou individual. O hukou é o sistema de registro, identificação e mobilidade geográfica. Consiste em um livreto de registro domicílio municipal com variedades em cada província chinesa. Além disso, controla a mobilidade por meio da autorização obrigatória individual ou familiar da residência entre as áreas rurais para urbana. Esse sistema foi criado em 1958 pelo Partido Comunista governado por Mao Zedong (1949-
} 
$|36|$

Uma etnografia da comunidade chinesa...

Para que voltar para lá? Nós somos da China, mas alguns de nós não queremos voltar. A maioria já é daqui. Ir para lá vai ser problema porque somos chineses, mas somos brasileiros. Os que voltaram para China e trocaram o hukou não são felizes e não têm emprego bom como tem aqui. (Ena, filha de chineses, 28 anos).

Devido ao engarrafamento que teve duração de mais de uma hora pudemos conversar sobre o hukou. Confesso que percebi que Ena ficou irritada quando quis saber sobre o registro domiciliar chinês de alguns membros da família dela e também de chineses em São Gonçalo, mas, quis tentar a sorte e instigá-la. Fui direto e perguntei sobre o que ela achava do hukou e o motivo de viver em São Gonçalo. Ela me olhou e disse:

\begin{abstract}
Eu não entendo! Confesso que acho estranho ser brasileira e ser chinesa ao mesmo tempo. [...] Já tentei, mas consigo ser apenas uma ou outra. Eu até sei que sou as duas coisas, mas não sei se sou primeiramente chinesa e depois brasileira, ou, sou primeiramente brasileira e depois chinesa. [...] eu posso ser o que eu quiser dependendo do que será bom no momento. Ser chinesa ou brasileira vai depender do que pode ser melhor. Não acredito que terei um hukou, até acho que não quero. Ter hukou é ser chinesa e eu já sou! Mas ser chinesa com documento acho que pode ser complicado. Lá no futuro... [pensativa] Eu for chinesa com documentos,
\end{abstract}

1954) com finalidade de impedir o grande êxodo rural e também perseguir os adversários do regime comunista. Como medida para coibir as maciças migrações para as cidades, o Partido Comunista atribuiu para cada cidadão um hukou que permite que cada pessoa apenas acesse serviços básicos como saúde e educação na cidade em zonas urbana ou rurais do registro de nascimento. Ademais, o sistema hukou possibilita o controle da população pelo governo com informações pessoais, tais como religião, escolaridade, estado civil, dados sobre nascimento, profissão, endereço residencial, ficha criminal e registro de mobilidade. Entre as décadas de 1950 a 1970 esse sistema de controle da população impediu movimentos migratórios sem autorização da população pelo Partido Comunista. 
passaporte e tal... Devo herdar o hukou da minha família. Eu não sei se quero viver como eles no interior ou viver em Guangdong como uma morta viva. Viver como uma morta

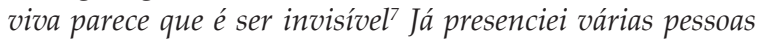
nessa situação. Posso dizer que não quero. Minha mãe fala para eu voltar para Guangdong e viver com ela, só que fico pensando... Viverei como uma morta viva igual minha mãe e aos outros. Edivan, eu sou brasileira, tenho passaporte daqui. Não quero ir para China e viver assim. Mas se eu for... [pensativa] Não poderei viver como estrangeira e deixar minha família do jeito que estão. É muito errado, seria uma traição muito grande. Prefiro viver com meu pai aqui. Viver aqui não vai me fazer traidora da minha mãe e tios lá na China. Não moraria com eles e morarei aqui no Brasil. Olha que em São Gonçalo não é o melhor lugar, mas é o que tenho. Se tudo der certo vou ter minha loja no Alcântara, né? Aqui é muito bom para ter algum negócio... Já tive muitos problemas por causa do hukou e não quero passar... Na verdade isso nem é meu. Eram dos meus pais que nem moram aqui, são deles [familiares] e por isso estou me fudendo nessa merda de briga de família. Meu sonho é juntar dinheiro, chegar na casa da minha mãe dar o dinheiro nas mãos dela para comprar um novo hukou (Ena, filha de chineses, 28 anos).

O depoimento emocionado de Ena dentro do ônibus me fez refletir sobre as condições e condicionantes da sua vida. Em setembro de 2012, o seu irmão mais novo, chamado Lucas, de 21 anos, após sair do banco foi seguido por dois rapazes de motocicleta, anunciaram o assalto e roubaram o celular e o alvejaram com três tiros. Eu me lembro dessa história quando iniciei minhas pesquisas na graduação e soube do assassinato do Lucas. Ena ainda vive o luto da morte do irmão e o medo constante de ser assaltada e

\footnotetext{
7 Referência ao contingente de chineses oriundos do interior da China que trabalham em cidades localizadas nas ZEEs sem autorização do Partido Comunista. Essa população é conhecida como "população flutuante".
} 
desde aquele crime evita andar na rua sozinha. Nas conversas que tivermos nas semanas anteriores, Ena comentou que a morte do irmão foi a causa do divórcio de seus pais. $O$ pai dela não quis voltar para China decidindo viver em São Gonçalo. Já a mãe, não aguentou morar no Brasil por achar que o País tirou a vida do filho e por isso voltou para China. Ena não gosta de comentar esse assunto pessoal e sente ter os pais morando em países diferentes e não poder cuidar deles na velhice.

Durante as conversas que tive com Ena ao longo da pesquisa de mestrado, soube que o corpo do seu irmão foi enterrado na China. Como pesquisador e principalmente por estar próximo dela ao longo da pesquisa, evitei comentar o assunto que a deixava triste. A opção de enterrar o corpo de Lucas na China se deve à ideia de retornar às origens familiares e também nacionais. Através das minhas observações e participação em conversas, soube que os chineses que decidem viver por definitivo no Brasil ou em outros países pedem, antes de morrerem, aos filhos e netos que enviem seus corpos para a China com intuito de serem cremados ou enterrados. Essa escolha se baseia na ideia de que é preciso que voltem para casa onde estão as origens dos ancestrais. Em uma breve conversa que tive sobre o falecimento de Lucas, Ena declara, em aparente contradição às declarações anteriores: É preciso voltar para casa, a China sempre será nossa mãe (Ena, filha de chineses, 28 anos).

Ela ainda relatou que alguns brasileiros perguntaram se a família dela não tinha vontade de realizar algum culto pelo óbito do irmão, entretanto, eles não quiseram por serem ateus. A decisão de que o irmão mais novo de Ena fosse enterrado na China era baseada na esperança de que as futuras gerações lembrassem dele, mas não estava vinculada a nenhuma religião. “O culto aos ancestrais é central na família e na sociedade chinesa e estende para além da morte o sentimento de solidariedade que une diferentes gerações" (TREVISAN, 2014, p. 160).

Em minhas observações descobri que a maioria dos chineses não são adeptos a nenhuma religião, no entanto alguns são filiados à Igreja Evangélica localizada em Nova Iguaçu. Os chineses que 
optam em se denominarem pertencentes a alguma religião o fazem apenas por interesse de socialização com os brasileiros. Pude notar ainda que a maioria cultua os ancestrais em caráter de respeito e a eles pedem proteção e sorte nas decisões ao longo da vida.

A morte de Lucas, entre os chineses nas cidades de São Gonçalo e Niterói foi encarada com medo e revolta. O medo na comunidade sínica se deveu à consciência de que a vítima poderia ser qualquer um de seu coletivo. Eles ficaram indignados com a morte de um jovem, mas preferiram não chamar atenção e manter discrição. Devido à morte de Lucas, o receio dos chineses de que as autoridades brasileiras descobrissem os chineses que estavam com documentação irregular, ou mesmo sem autorização de residência no País, aumentou a tensão entre eles. Ademais, a desconfiança dos chineses em relação aos brasileiros também aumentou significativamente.

Durante minhas experiências etnográficas com chineses pude observar que os brasileiros são vistos como trapaceiros, ladrões e mentirosos. Ao longo da minha vivência com o grupo sínico do leste metropolitano fluminense tive conhecimento de muitos casos de furtos de produtos em lojas de chineses e assaltos realizados por brasileiros. Ainda soube de breves relatos por parte dos chineses que foram vítimas de golpes de clonagem de cartões de crédito e celulares. Ao longo da pesquisa pude perceber os estigmas que os brasileiros sofrem quando entram nas lojas e lanchonetes de chineses em São Gonçalo, contudo esses não percebem. Os brasileiros são atentamente observados nas lojas e lanchonetes dos chineses por serem tomados como possíveis ladrões interessados em roubar o dinheiro do caixa ou os produtos à venda. Já os brasileiros que são contratados pelos chineses para trabalharem em seus estabelecimentos em cargos de segurança, atendente de balcão, cozinheiro, auxiliar de serviços gerais e repositor de produtos são também vigiados pelos chineses com receio de serem furtados durante o trabalho.

Nas lanchonetes, os chineses possuem conhecimentos da língua portuguesa para atenderem brasileiros em seus pedidos, contudo, optam em contratar brasileiros para atrair clientes. 
$|40|$

Uma etnografia da comunidade chinesa...

Segundo relatos obtidos no campo, mesmo com os estigmas que os brasileiros têm por serem conhecidos como trapaceiros, eles são contratados pelos chineses. Os depoentes relataram que têm conhecimentos que os brasileiros têm receio dos hábitos de higiene dos chineses eque evitam consumirem os alimentos das lanchonetes. Dessa maneira, para atrair clientes brasileiros, contratam outros brasileiros para serem atendentes das lanchonetes. De acordo com os depoentes, os brasileiros aparentam ser mais limpos e por isso são bem-vistos por outros brasileiros por acreditarem que são eles que preparam os alimentos. Os brasileiros quando ver um brasileiro na vitrine vendendo aceita comer do que quando somos nós. Isso é bom podemos ganhar mais dinheiro (Ena, filha de chineses, 28 anos).

Em minhas participações nas cozinhas das lanchonetes, observei que os brasileiros que são contratados para atenderem os clientes também preparam os alimentos junto com os chineses ${ }^{8}$. Dessa maneira, essa estratégica étnica dos chineses em empregar brasileiros como atendentes evita perda de consumidores. Ainda observei que os brasileiros trabalham de atendentes, preparam os alimentos e são responsáveis pela limpeza, mas não são permitidos que recebam o dinheiro dos clientes e não podem ficar responsáveis pelo caixa que na opinião dos chineses são compreendidos como trapaceiros. De acordo com Ena: os brasileiros podem ficar na cozinha, limpar chão e falar com outro brasileiro para comer. Brasileiro não pode guardar dinheiro [sic] Ena, filha de chineses, 28 anos).

Devido minhas primeiras experiências na juventude e em seguida acadêmicas ao longo dos anos com chineses tentei me despir dos estereótipos que pesquisadores brasileiros têm ao estudarem chineses, buscando a possibilidade de me inserir no grupo estudado de maneira mais legitima sem preconceitos. Contudo, passei a conhecer os estereótipos que os chineses têm dos brasileiros.

${ }^{8}$ Nas cozinhas das lanchonetes em que entrei, observei que os chineses dormiam sobre os sacos de trigos e que tinham pertences pessoais. Em duas situações presenciei camas e esteiras nas quais os chineses dormiam. 


\begin{abstract}
O campo das sensibilidades é, sem dúvida, o que gera maior estranhamento, porque toca no âmago da diversidade cultural e da intersubjetividade. Relacionar-se com o Outro é muito mais denso e dramático do que comer um exótico prato de ensopado de cachorro. Longe de casa, sentir-se acolhida (e não solitária) na companhia de um nativo é, em meu ponto de vista, o principal desafio do campo. Isso remete a uma questão fundamental no estudo dos chineses por brasileiros, a qual versa sobre dois estereótipos culturais que, como muitos estereótipos são baseados em traços concretos: a ideia de um povo aberto, de um lado; e de um povo fechado, de outro (PINHEIROMACHADO, 2009, p. 29).
\end{abstract}

Ao longo da pesquisa pude sentir a desconfiança dos chineses em relação aos brasileiros, afinal, eu sou brasileiro. Em minhas tentativas em estabelecer contato com os chineses fui tratado de maneira ríspida e grosseira. Sempre com desconfiança sobre o que eu estava fazendo naquele lugar. Quando me apresentava como pesquisador muitos não sabiam o significado da palavra ("pesquisador" e similares, tais como "pesquisa", investigação"), mesmo após a minha explicação continuavam sem compreensão. Houveram momentos que percebia que eles compreendiam o que eu falava e fingiam que tinham pouco conhecimento na língua portuguesa, como estratégia para evitar conversar comigo e forçar minha partida. É preciso ainda destacar que a timidez dos chineses foi uma barreira para a aproximação, o que inicialmente dificultou estabelecer o contato. Como pesquisador, tive vergonha em abordar os chineses e estabelecer contato. Em minhas tentativas eu era observado por chineses e brasileiros, que estranhavam minhas tentativas em querer conversar.

De acordo com Pinheiro-Machado (2009, p. 28): “Trata-se de uma experiência plena, em que a barreira do pré-conceito só e vencida se estamos abertos a passar por experiências novas, mesmo as mais difíceis, tolas ou desconcertantes". Houveram situações, após minha apresentação e explicação do meu objetivo, em que 
fui tratado de maneira agressiva. Algumas vezes fui expulso com gritos, palavras de ordem e empurrado para fora da loja ${ }^{9}$ e até jogaram refrigerante em minha cabeça quando entendiam que não compraria nada. Devido às minhas experiências como pesquisador, sabia das dificuldades que teria de inserção no grupo étnico chinês por ser brasileiro e pertencer a outro grupo étnico. Meus contatos com chineses podem ser compreendidos através das leituras de Barth (2000) ao analisar as diferenças entre os grupos étnicos - eu na categoria de pesquisador brasileiro e os depoentes chineses - estabelecemos modos de divergentes entre grupos, a importância se baseia na consideração das culturas atreladas ao modo organizacional étnico. Ao longo da pesquisa, houveram dias em que pensei em abandonar a pesquisa devido ao tratamento grosseiro recebido pelos chineses e até dos colaboradores. Em outras circunstâncias fui chamado de vagabundo e ladrão pelos chineses e até funcionários brasileiros que me viam como perigo por acharem que eu tinha interesse em ocupar os empregos deles. Nas leituras dos trabalhos da antropóloga Rosana Pinheiro-Machado (2009) que investigou a rede formal e informal de circulação dos produtos chineses no comércio entre a China, Paraguai e Brasil relata as mesmas impressões que tive ao longo da pesquisa ${ }^{10}$.

No Paraguai e na China, eu buscava proximidade e afetividade nos relacionamentos [com chineses]. Almejava a facilidade da comunicação que eu tinha tido com os camelôs - comunicação esta que vai muito além da linguagem e diz respeito ao entendimento interpessoal. No entanto, era percebida com desconfiança por parte de muitos informantes,

\footnotetext{
${ }^{9}$ Certa vez, fui empurrado, caí no meio-fio da calçada, o que me deixou machucado.

${ }^{10}$ PINHEIRO-MACHADO, Rosana. Made in China: Produção e circulação de mercadorias no circuito China-Paraguai-Brasil. Tese (Doutorado em Antropologia Social), Universidade Federal do Rio Grande do Sul. Porto Alegre. 2009. Disponível em: http://www.lume.ufrgs.br/handle/10183/16895. Acesso em: 15 de março de 2016.
} 
que ressaltavam a maneira imediatista com que os brasileiros lidavam com a vida. Amizade instantânea era vista como cinismo, pois o vínculo construído rapidamente podia ser reverter em briga, também rapidamente. Encontrei muitas caras fechadas, recebi muitos "nãos". Levei empurrões tentando entrar em trens ou atravessar a rua, bem como fui expulsa algumas vezes de lojas quando o vendedor via que eu não compraria nada. Enfim, briguei, chorei de raiva. Encontrava um mundo que se mostrava áspero e frio: essa sim era a diferença intransponível (PINHEIROMACHADO, 2009, p. 30).

Como a pesquisadora, chorei ao pensar que talvez não conseguisse desenvolver a pesquisa ${ }^{11}$, achei que seria impossível estabelecer contatos com chineses por negarem conversar comigo e ignorarem minha presença. Em muitos momentos quando estive em campo me senti sozinho mesmo estando próximo da minha casa. Paradoxalmente, eu me sentia distante por tentar estar em um grupo étnico que em alguns momentos não me aceitava ou que me olhavam com desconfiança sem compreender minha presença.

\section{3 - O ano é do Galo: comemorações do ano novo Chinês}

No dia 29 de janeiro de 2017, quando cheguei com Ena ao espaço alugado pelos chineses para comemoração do Ano Novo, percebi que o local estava decorado com os símbolos dos doze animais do zodíaco chinês, mas o Galo estava em destaque através de gravuras pelas paredes. As cores predominantes para decoração eram vermelhas e amarelas, que estavam representadas pelas toalhas de mesa e cadeiras. $\mathrm{O}$ local tinha cheiro agradável de comida, no qual se destacava o assado da carne de porco.

Nos primeiros momentos da minha chegada fui o centro das atenções. Eu pude observar que todos os olhares estavam sobre

\footnotetext{
${ }^{11}$ Até pensei em mudar de pesquisa e investigar os movimentos migratórios de senegaleses no município de Niterói.
} 
mim por não ser chinês. Ena pediu para que eu segurasse a bolsa dela enquanto ficava na cozinha preparando os pratos. A princípio achei o pedido dela comum, entretanto, há significados diferentes entre os chineses quando um homem segura bolsa de uma mulher que explicarei mais à frente. Logo de início verifiquei uma divisão de gênero nas tarefas de organização, onde as mulheres preparavam os alimentos rapidamente e organizavam as mesas, enquanto os homens ficaram pelo salão conversando baixo.

Meu fenótipo é diferente dos chineses - da etnia han que ocasionou olhares sobre mim, escutei em diversos momentos duas palavras em mandarim waiguoren e iaowai que significam em português, estrangeiro. Alguns acharam que eu tivesse outra nacionalidade (acharam que eu fosse europeu ${ }^{12}$ ), mas não que eu fosse brasileiro devido à minha aparência. Houveram momentos que percebi que eu não era apenas o centro dos olhares, eu era fotografado por ser alguém diferente deles naquele momento exclusivo dos chineses. Mesmo com olhares de estranhamento por alguns, fui educadamente recebido.

Levei meu diário de campo, todavia, achei melhor não fazer observações escritas para não chamar mais atenção e tentar me inserir entre eles. A comemoração teve duração de quatro horas com celebrações ao Galo - animal sagrado - e ocorreram conversas entre pequenos grupos. Tentei me inserir nos grupos dos jovens, homens e mulheres, mas era rejeitado. Percebia que os chineses conversavam em cantonês ${ }^{13}$ e percebi que a língua era um obstáculo que precisava enfrentar para minha inserção nas fronteiras étnicas chinesas. Minha experiência de inserção etnográfica me deixava

\footnotetext{
${ }^{12}$ Pude observar que norte-americanos que residem nos municípios do Leste Metropolitano, vinculados às igrejas protestantes mórmons e, sobretudo europeus (portugueses e espanhóis) são compreendidos como ricos por serem oriundos de países centrais e por serem pessoas brancas. Certa vez, uma senhora chinesa achou que fosse rico por acreditar que eu fosse europeu e branco.

13 Dialeto falado na província de Guangdong também denominada em português como Cantão, localizada no sul da China.
} 
frustrado por não conseguir manter o contato necessário e confesso que preferiria até ser destratado, pois assim teria conhecimento da reação deles, mas fui apenas ignorado. Ninguém quis conversar comigo e isso me isolou. No ano de 1958 quando Clifford Geertz (2008) realizou a sua pesquisa em uma aldeia balinesa, Indonésia, relatou sua experiência parecida com a minha quando efetuou sua etnografia sobre as brigas de galos ${ }^{14}$.

[...] Enquanto caminhávamos sem sentindo, incertos, ansiosos, dispostos a agradar, as pessoas pareciam olhar atrás de nós, focalizando o olhar a alguma distância, sobre uma pedra ou uma árvore, mais reais do que nós. Praticamente nos cumprimentavam, mas também ninguém nos ameaçavam ou dizia algo desagradável, o que seria até mais agradável do que ser ignorado. Quando nos arriscávamos a bordar alguém (e numa atmosfera como essa a pessoa sentese terrivelmente inibida para isso), essa pessoa se afastava, negligente, mas definitivamente. Se ela estivesse sentada ou apoiando-se a uma parede e não pudesse afastar, simplesmente não falava nada ou murmurava aquilo que representa para balinês uma não-palavra "yes". A indiferença, sem dúvida, era estudada; os aldeões vigiavam cada movimento que fazíamos e dispunham de uma quantidade enorme de informações bastante corretas sobre quem éramos e o que pretendíamos fazer. Mas eles agiam como se nós simplesmente nãos existíssemos e esse comportamento era para informar que de fato nós não existíamos, ou ainda não existíamos (GEERTZ, 2008, p. 185, grifo nosso).

Tentei conversar com Ena para, com sua ajuda, penetrar no grupo, porém ela estava ocupada preparando as comidas. Eu estava ficando desestimulado. Sentei em um canto e, olhando para eles,

14 GEERTZ, Clifford. "Um jogo absorvente: Notas sobre a briga de galo balinesa". In: A interpretação das culturas. Rio de Janeiro: LTC, 2008. 
pensei na razão de estar ali, afinal os presentes não queriam saber de mim. Indo ao banheiro antes de ir embora, encontrei um senhor de 58 anos chamado Xiao, bem-humorado e que falava português com forte sotaque mandarim. Ele mora em Botafogo e tem dois filhos que vivem em Vancouver, Canadá - que moram desde 2010 para estudarem em universidades canadenses. Consegui manter meu único contato com um chinês na comemoração do Ano Novo Chinês. Ele comentou brevemente sobre sua vida no Brasil. Xiao trabalhou por muitos anos como vendedor de produtos chineses na cidade do Rio de Janeiro, em Madureira e na Sociedade de Amigos das Adjacências da Rua da Alfândega (conhecido popularmente como SAARA), conjunto de ruas ocupadas pelo comércio popular localizado no Centro. Após anos trabalhando como vendedor abriu duas lojas em Madureira, uma em Duque de Caxias e uma em São Gonçalo. Xiao relatou que participa das decisões, remunerações e gastos de suas lojas, entretanto, quem administra são seus irmãos e sobrinhos que vivem no Rio de Janeiro. Em nossa breve conversa, ele disse que gosta de trabalhar na região metropolitana do Rio de Janeiro e ajuda a sua família no Brasil e na China.

A conversa que tive com Xiao me retomou a esperança, decidi ficar por mais tempo na festa do Ano Novo e buscar estabelecer contatos com outros chineses, mas as expectativas foram frustradas. Nas tentativas que fiz, fui rejeitado e ignorado. Houveram momentos que estabeleci contato em português, mandarim e em inglês como possibilidade de iniciar conversas, mas acabava sendo visto como "intruso" que avançava as fronteiras do grupo étnico chinês em São Gonçalo ${ }^{15}$

15 "Dada a ênfase na dimensão desses grupos como portadores de cultura, a classificação das pessoas e dos grupos locais como membros de um grupo étnico necessariamente depender da presença de traços culturais particulares. Na tradição das áreas culturais, isso é algo que pode ser julgado objetivamente pelo observador etnográfico, sem que se leve em conta as categorias e preconceitos dos atores. Diferenças entre os grupos tornam-se diferenças entre inventários de traços: a atenção concentra-se sobre a análise das culturas, em detrimento da organização étnica". (BARTH, 2000, p. 29). 
Utilizo aqui grupo étnico no sentido que Barth atribui: "Ao enfocar aquilo que é socialmente efetivo, os grupos étnicos passam a ser vistos como uma forma de organização social" (BARTH, 2000, p. 31). A organização social dos chineses na cidade de São Gonçalo se baseia por valores culturais da sociedade chinesa que corroboram para constituição de sua identidade étnica, que pode ser verificada através da hierarquização das relações familiares, superstições, crenças em números que influenciam a sorte ${ }^{16}$, casamentos arranjados pelos pais, crença nos animais do zodíaco chinês etc.

A comemoração do Ano Novo é realizada desde 2014 e é um evento fechado, somente para chineses que residam em São Gonçalo e cidades adjacentes, idealizado por um grupo de amigos chineses. A comemoração do ano em 2017 festava o início do ciclo do Galo, animal do horóscopo chinês, que simboliza o trabalho que proporciona ganhos financeiros. O clima de otimismo no jantar de comemoração do Ano Novo era mantido por cinco famílias de proprietários de lojas e lanchonetes ${ }^{17}$ que totalizava 37 pessoas que se comunicavam majoritariamente em cantonês e mandarim.

$\mathrm{O}$ jantar servido às $16 \mathrm{~h}$ era farto e com comidas típicas chinesas. Com muitos peixes fritos sendo servidos por inteiro em grandes pratos, pastéis recheados de carne preparados em forma de lingotes e bastante carne de porco por simbolizar prosperidade e a sorte. Haviam muitos tipos de chá, todavia, predominavam o

\footnotetext{
${ }^{16}$ Durante minhas observações sobre os chineses percebi que eles não moram no quarto andar dos prédios e também evitam alugar apartamento que tem o número "quatro". O som da palavra "quatro" em mandarim é parecido com o da "morte". Assim, os chineses evitam morar no quarto andar dos prédios. Os chineses escolhem morar no oitavo andar dos prédios devido ao som do "oito" é parecido com em mandarim com riqueza, sorte e sucesso. Através das minhas observações percebi que os chineses moram no oitavo andar dos prédios residenciais de São Gonçalo, é possível ter mais de três famílias morando em apartamentos diferentes.

${ }^{17}$ Através de conversas com chineses e da observação participante soube que os estabelecimentos comerciais desse grupo se concentram nos bairros do Alcântara e Centro.
} 
verde e o preto. Nas mesas de bebidas havia cerveja de marcas brasileiras e europeias e bastante água. Existia bastante sorvete que era consumido principalmente pelas crianças, que pareciam sofrer com o forte calor. No salão de festas encontravam-se várias mesas com capacidade para oito pessoas. Observei ainda que os chineses se agrupavam nas mesas pelas faixas etárias.

Em minhas frustrantes tentativas de inserção no grupo achei que seria melhor ficar próximo de Ena por ser minha referência naquele grupo. Em minha nova tentativa de saber mais sobre aquelas pessoas, questionei-a sobre quem eram as pessoas presentes naquela comemoração. Ela relatou que a maioria dos participantes morava em São Gonçalo e alguns em outras cidades - Rio de Janeiro e Itaboraí. Todos eram pequenos empresários com estabelecimentos de lanchonetes e/ou lojas de produtos importados da China e que majoritariamente eram nascidos ou viveram na província de Guangdong. Perguntei sobre quais seriam os motivos para comemorações do Ano Novo em São Gonçalo. Ena disse que todos são se ajudam um ao outro quando é necessário ${ }^{18}$. Além disso, é importante se reunirem para perpetuar as redes de relacionamento e ajuda mútua. Após a breve explicação da minha depoente, fiquei ainda mais curioso para entender aquele grupo e suas redes de sociais.

Nesse momento, percebi que estava diante de algo que ainda não consegui detectar em meus estudos sobre imigração chinesa: guanxi. Essa expressão da língua chinesa tem como significado relacionamento com objetivos específicos que pode ser financeiros, parcerias políticas, comerciais etc., e que precisam ter como base o respeito e confiança. O guanxi se define como rede de parcerias entre membros que possuam ajuda mútua. Além do território da China, as práticas do guanxi costumam estar atreladas ao trabalho

\footnotetext{
${ }^{18}$ Segundo Eric R. Wolf (2003, p. 246): "Quando olhamos para os fenômenos étnicos (no sentido de esforços para sustentar a solidariedade de grupos mediante apelos aos atributos comuns de descendência e tradição), vemo-nos diante de uma gama muito mais ampla de circunstâncias que geram o que parecem ser efeitos similares".
} 
e comércio ilícito por chineses e descendentes, pois que na China são fundamentais em setores do país que perpassam a indústria, economia, política e cotidiano da população (SILVA, 2008). Assim, percebi que guanxi é uma prática comum entre os chineses, a qual apresentarei mais à frente.

No final da minha participação na comemoração do Ano Novo Chinês, eu já estava cansado devido ao calor que era forte. Além disso, havia o agravante que as telhas do salão eram de zinco, que intensificaram ainda mais o calor. Optei em voltar junto com Ena com interesse de saber informações que não consegui obter de imediato. Na despedida fiquei mais tímido do que quando cheguei, eu não sabia como poderia realizar minha despedida e agradecer por terem me aceito. Acabei dando um adeus coletivo e todos me olharam e não expressaram nenhuma reação. Saí daquele local como se tivesse realizado algo de errado, mas não sabia o que seria.

Na volta fomos juntos de ônibus até o Centro de São Gonçalo, na viagem Ena relatou que os participantes ficaram surpresos com minha presença e que de acordo com ela foi inédita. Não seria proibido que alguns brasileiros participassem, mas foi grande surpresa para eles. Ninguém imaginaria que eu levaria um brasileiro (Ena, filha de chineses, 28 anos). Questionei se por acaso ela foi criticada por ter me levado e para meu conhecimento, os chineses pensaram que Ena e eu tínhamos algum relacionamento. De acordo com Ena, a maior surpresa foram eles terem achado que nós tivéssemos um relacionamento amoroso. Ela disse que a maior parte do tempo em que estava na cozinha foi questionada pelos chineses se nós estávamos namorando e se casaríamos em breve. $O$ maior susto não foi você ter ido, foram eles terem achado que nós fossemos namorados (Ena, filha de chineses, 28 anos). Após esse comentário eu ri dos participantes por terem acreditado nessa possibilidade e questionei se Ena havia comentado sobre o motivo da minha ida à comemoração do Ano Novo. Ela respondeu com risos e disse: $E u$ não sei bem (Ena, filha de chineses, 28 anos).

Após ela fazer esse comentário fiquei em silêncio por alguns segundos e lembrei que ela pediu para que segurasse a bolsa na 
frente dos chineses que estavam presentes. Lembrei-me ainda dos meus primeiros contatos que tive com chineses em minha adolescência e sobre o costume dos homens segurarem a bolsa das mulheres. Entre os chineses, quando um homem segura a bolsa da mulher significa que eles estão em um relacionamento sério ou estão casados. Através das minhas convivências pude observar que os namoros dos chineses são compreendidos como estágio do início do casamento. Os chineses não costumam ter namoros longos, os namoros são curtos e eles casam logo depois. Comentei se ela sabia ou tinha noção das atitudes que teve em relação a mim quando estávamos na comemoração. Ela riu e respondeu: Não foi nada demais. Achei engraçado eles achando que eu tenho um namorado brasileiro (Ena, filha de chineses, 28 anos). Eu fiquei incomodado com a atitude dela por achar que fui usado para uma "brincadeira".

Expliquei desde o início de nossas conversas sobre meu objetivo como pesquisador. Minha preocupação cresceu devido à atitude dela, que poderia prejudicar minha inserção no campo. Ela percebeu que fiquei chateado e não conversamos até chegarmos ao Centro de São Gonçalo, quando cada um de nós foi para nossas casas. Após a comemoração do Ano Novo Chinês encontrei com Ena algumas vezes enquanto caminhava pelas ruas do bairro do Centro e Porto da Pedra.

\section{4 - Etnográfico: cliente observador externo e estranho participante interno}

Entre os meses de outubro a dezembro de 2016, frequentei uma lanchonete de propriedade de imigrantes chineses, localizada na Avenida Presidente Kennedy no Centro de São Gonçalo, na tentativa de realizar uma aproximação gradual com os chineses que trabalhavam no local. Frequentei a lanchonete duas vezes na semana em dias aleatórios, esperando que minha presença fosse naturalizada pelos chineses com objetivo tentar estabelecer contato mais profundo. Minha entrada no campo a princípio foi como cliente que sentava na bancada e consumia. Logo após, busquei estabelecer confiança e de alguma maneira ser útil 
para eles. Baseado em William Foote Whyte (2005) iniciei como cliente observador externo. No decorrer do tempo, quando passei estabelecer confiança, passei a ser a princípio cliente participante não-observador interno.

Nos primeiros meses em Cornerville, vivi o processo do sociólogo Robert Johnson descreveu em seu próprio trabalho de campo. Comecei como observador não participante. À medida que fui aceito na comunidade, vi que me tornava quase um participante nãoobservador. Tinha de sentir a vida em Corneville, mas isso significava que devia tomar como dados os mesmos aspectos que meus amigos de Cornerville consideravam como tal. Encontrava-se imerso na vida local, mas ainda não conseguia que as coisas adquirissem sentido para mim. Tinha a impressão de que fazia algo importante, mas faltava explicar a mim mesmo do que se tratava (WHYTE, William Foote, 2005, p. 318).

A referência etnográfica de William Foote Whyte (2005) contribuiu para minha sensibilidade como pesquisador com a necessidade de aprofundar ainda mais no campo. Assim, caracterizo minha inserção neste campo em dois momentos diferenciais: 1 - Cliente observador externo e $\mathbf{2}$ - Estranho participante interno. Esses dois marcos diferenciais no campo foram relevantes para que pudesse compreender as dinâmicas das relações ocorridas no espaço da lanchonete.

\subsection{Cliente observador externo}

À tarde, o clima era quente devido à aproximação do verão. Busquei sentar no interior da estreita lanchonete onde a luz do sol não alcançava ${ }^{19}$. Sentar no último espaço da bancada ou nas últimas cadeiras proporcionava uma visão ampla sobre

\footnotetext{
${ }^{19}$ Nesses dias a sensação térmica em São Gonçalo ficou na faixa entre 32 a 42 graus centigrados.
} 
as dinâmicas ocorridas naquele espaço. Com a perspectiva propiciada pela localização, podia observar o atendimento dos clientes e desempenho das demais atividades comuns a aquele tipo de serviço. Nesse momento observava e descrevia em meu caderno de campo as gesticulações, as relações entre aqueles atores da diáspora chinesa e também entre eles e os clientes brasileiros. $\mathrm{O}$ cheiro de assados e frituras que aquela lanchonete tinha era possível de sentir quando passava pela calçada em frente. Observei que alguns moradores de rua compravam seus lanches e caminhavam até a Praça Estephânia de Carvalho - conhecida popularmente como Praça do Zé Garoto - e comiam pelos arredores. Em alguns momentos, as tentativas de compreender as suas falas eram frustradas devido à frequente troca de língua que alternava o uso da língua cantonesa, o Mandarim e o Português. $\mathrm{O}$ ambiente da lanchonete possui elementos característicos da cultura chinesa como os quadros de paisagens da China e ideogramas chineses. Além disso, haviam retratos de Mao Zedong e de familiares que vivam na China.

Durante as idas à lanchonete, como cliente observador externo, realizei tentativas de comunicação por meio de cumprimentos em português e perguntas sobre os elementos da diáspora chinesa que pudessem estimular o diálogo entre nós. Eles não apresentaram interesse em estabelecer um canal de conversa. As respostas eram sorrisos e as vezes diziam: [Eu] Agora não posso (Xanadu, chinesa, aproximadamente 55 anos). Minhas tentativas de inserção no grupo eram frustradas e em alguns momentos pensei em desistir por não conseguir sequer criar um vínculo. Durante duas vezes na semana até o final do mês de novembro de 2016 realizei as mesmas tentativas de aproximação como cliente que sentava no último assento da lanchonete, pedia meu lanche e no final tentava conversar sobre algum assunto que remontava à imaginada comunidade chinesa. Gradualmente consegui estabelecer conversas com frases curtas em português que foram limitadas a princípio devido à barreira da língua. Mesmo com as primeiras dificuldades, insisti com perguntas relacionadas à China como estratégia em acionar as lembranças afetivas e assim 
estimulá-los ao diálogo. Percebi que no início das conversas eles conversavam em português de maneira limitada, com poucas palavras, mas ao longo do tempo eles apresentaram vocabulários mais complexos. Durante o mês de dezembro percebi que eles conseguiam se expressar em português. Todavia, conversavam comigo em poucas palavras e costumavam dizer que não sabiam falar a língua portuguesa.

Minhas idas à lanchonete possibilitaram contatos mais próximos aos chineses e proporcionaram meu status de cliente observador externo como sujeito mais próximo daquele cotidiano. Minha maior aproximação entre os chineses da Lanchonete A foi com o jovem Quon de 25 anos. Minhas idas a campo para iniciar minhas investigações sobre as migrações chinesas no leste metropolitano fluminense passaram não exigir mais do artifício do consumo em lanches por ter construído vínculo de amizade com o rapaz, contudo, quando eu precisava ir ao banheiro era necessário pagar $\mathrm{R} \$ 1,00$ a cada vez que fosse.

Devido à amizade, passamos a nos encontrar na entrada do Shopping Patarge, que fica próximo à lanchonete para conversarmos sobre a China e sobre a imigração da família dele. Quon relatou que nasceu na capital de Assunção no Paraguai e veio ao Brasil na adolescência com seus pais, onde viveu por curto período em São Paulo e Duque de Caxias até se estabelecer em São Gonçalo. Durante as primeiras conversas no shopping percebi que Quon falava português fluentemente. Em nossas voltas pelas vitrines e corredores do shopping ele relatou que tinha lembranças de quando vivia com seus pais e irmãos na capital do Paraguai. Quon comentou que seu tio morava em Assunção e convidou o pai dele para viver com a família no Paraguai, pois, já haviam chineses e taiwaneses residindo no país, o que facilitava o estabelecimento dos imigrantes ${ }^{20}$. Logo que a família chegou, os pais e irmãos

\footnotetext{
${ }^{20}$ Durante a pesquisa percebi que os chineses mantinham vínculos com familiares e comerciais em outras cidades brasileiras, tais como, São Paulo, Curitiba, Campinas, Belo Horizonte e, em outros países, Reino Unido, Espanha, Argentina, Estados Unidos, Rússia e Canadá.
} 
Uma etnografia da comunidade chinesa...

trabalharam como vendedores de produtos fabricados em Guangdong de baixo valor ${ }^{21}$ e estudaram em uma escola taiwanesa onde aprendeu a falar o Guarani e o espanhol ${ }^{22}$. Ele relatou que convivia com vários chineses, que constituíam a maioria de seus amigos. Devido aos desentendimentos ocorridos ao longo dos anos entre o pai e o tio dele, motivados pelo trabalho na loja, resolveram migrar para São Paulo. A mudança para a capital paulistana foi difícil por não conseguirem se adaptar ${ }^{23}$ e mudaram para a cidade de Duque de Caxias na baixada fluminense. Ele e os familiares viveram em Duque de Caxias por apenas um mês. Logo tiveram interesse em se mudar para São Gonçalo, influenciados por chineses que naquele momento estavam de mudança. Ele relatou que sua família, com o objetivo de terem comércio próprio, arriscou a viver em São Gonçalo acreditando que seria mais fácil do que no Rio de Janeiro.

Quon chegou a São Gonçalo em 2004 com seus pais e irmãos e se estabeleceram no bairro do Zé Garoto. Os pais dele tinham contato de chineses que poderiam ajudar a importar produtos diretamente da China que eram vendidos por valores baixos em lojas de 1,99 onde todos os familiares trabalhavam. Eu percebi através da etnografia que trabalho em comércio da família é entendido pelos chineses como algo pertencente à coletividade. É considerado como patrimônio onde todos precisam contribuir para prosperidade e zelo, na medida em que é o rendimento e sustento familiar. A loja da família de Quon que ficava no Centro da cidade cresceu e permitiu que os pais juntassem dinheiro para que ele e seu irmão estudassem na China por três anos, aos cuidados dos avós maternos. Segundo Quon, os seus pais queriam que os filhos vivenciassem os valores da cultura chinesa.

\footnotetext{
${ }^{21}$ Produtos conhecidos popularmente como "Made in China".

${ }^{22}$ De acordo com Quon, a escola taiwanesa na qual estudou era composta por alunos taiwaneses e chineses que eram filhos de comerciantes e sacoleiros que moravam em Ciudad del Este.

${ }^{23} \mathrm{O}$ interlocutor não quis conversar sobre esse momento da vida. Observei que ele se sentiu desconfortável.
} 
Ao retornarem para São Gonçalo a loja de produtos 1,99 faliu devido ao fim dos acordos de compra coletiva dos produtos chineses entre a comunidade sínica. Sua família e outros chineses estabelecidos em São Gonçalo investiram em lanchonetes como forma de superar as falências das lojas de 1,99. Quon teve dificuldade em aceitar o novo trabalho da família devido à rotina diferente, mas durante as semanas seguintes após seu retorno se acostumou e passou a desempenhar funções do preparo dos alimentos junto com seu irmão. Trabalhar nas lanchonetes é muito cansativo que em loja, entendeu? Sempre tem comida para fazer. Eu sempre tenho uma queimadura quando estou fritando. [sic] (Quon, filho de chineses, 26 anos).

Morador da cidade de São Gonçalo, eu já havia notado que no final da década de 1990 e até o ano de 2005 existiam muitas lojas 1,99 pela cidade de São Gonçalo, concentradas predominantemente nos bairros do Centro e Alcântara. Questionei Quon sobre as causas que levaram ao fechamento da loja de sua família. De acordo com ele, São Gonçalo e os demais cidades da região do Leste Metropolitano - Niterói e Itaboraí são ótimos para abrir comércio devido à facilidade de acessar a metrópole do Rio de Janeiro e pela baixa disputa no comércio com brasileiros e até com outros chineses. Quon comentou que devido à pouca atuação da unidade da Polícia Federal de Niterói em querer saber regularização da documentação dos chineses - se possuem Visto de Residência para trabalharem em São Gonçalo. Além disso, em São Gonçalo há pouca fiscalização da Vigilância Sanitária para avaliar as lanchonetes.

Caso a Vigilância Sanitária queira fechar a lanchonete por causa das condições do lugar é muito ruim. Os chineses são obrigados a fechar a porta, jogam a comida fora. Depois disso podem descobrir que o chinês não tem autorização [Visto de Residência] para viver no Brasil (Quon, filho de chineses, 26 anos). 
Ele explicou que no Rio de Janeiro, São Paulo e na região fronteiriça entre Foz do Iguaçu (Brasil) e Ciudad de Este (Paraguai) há muitas disputas de mercados, que em vários momentos geram conflitos entre chineses por diminuírem os valores das mercadorias além do já acordado.

\begin{abstract}
As possibilidades existentes nos mercados brasileiros e a fuga do regime comunista para um país "seguro" são duas mais alegadas e divulgadas (especialmente pela imprensa) razões para sua opção. Em relação ao Rio de Janeiro, estima-se que a maioria dos chineses aqui instalados veios de São Paulo, em função da saturação do mercado e da atração das boas possibilidades oferecidas pelo estado (ARAÚJO, 2010, p. 227, grifo nosso).
\end{abstract}

Entre os anos de 1998 a 2005 os chineses em São Gonçalo anteriormente residiam na baixada Nova Iguaçu, Duque de Caxias, Rio de Janeiro, São Paulo e Paraguai - realizavam acordos entre eles na compra de produtos importados da China que entravam pelo Paraguai e em alguns casos pelo porto do Rio de Janeiro. A compra de produtos chineses para serem vendidos nas lojas chinesas ou serem revendidos aos camelôs brasileiros era cara para eles. Como solução, eles compravam juntos grandes quantidades de produtos da China, que eram importadas para o Paraguai e depois distribuídas na região metropolitana do Rio de Janeiro. Quando as mercadorias chegavam ao Rio de Janeiro ou em São Gonçalo, dividiam as partes proporcionais da compra para cada chinês. Quon relatou que vários grupos de chineses tinham esses acordos e conseguiam comprar por baixos valores os produtos diretamente com empresários na China que vendiam para compradores chineses e taiwaneses estabelecidos no Paraguai. Logo em seguida as mercadorias eram enviadas para São Gonçalo, Rio de Janeiro, Nova Iguaçu e Duque de Caxias.

"O tempo da produção de uma mercadoria na China até a mesma ser comprada num camelô ou numa loja do '1,99', pode levar no mínimo 45 dias [...]” (PINHEIRO-MACHADO, 2009, p. 
14). Para que fossem evitadas disputas por clientes entre chineses os produtos deveriam ser vendidos com preços tabelados. Dessa forma as mercadorias eram vendidas nos valores por $\mathrm{R} \$ 1,99, \mathrm{R} \$ 2,99$, $\mathrm{R} \$ 3,99$ e assim por diante. Caso algum chinês não respeitasse as regras, seria punido com expulsão dos acordos em compra coletiva. Caso um chinês seja expulso dos acordos, ficaria inviável comprar os produtos sozinhos por ficar caro para importar. Dessa maneira, não poderia continuar com a loja. Os estudos de Neiva Cunha e Pedro de Mello (2005), ao analisar as etnias e etnicidades de grupos de lojistas no mercado popular da SAARA no Centro do Rio de Janeiro, afirmam que as redes migratórias e de comércio de produtos chineses operam em códigos de condutas que reduzem as competitividades:

[...] os comerciantes provenientes da diáspora chinesa não estavam atrelados a modelos de financiamento e créditos convencionais do capitalismo ocidental. O sistema chinês funciona sobre regras de conduta, onde a cooperação dentro das redes e clãs reduz a competitividade. Isto não elimina a concorrência, mas há uma tendência maior ao associativismo de redes do que o desenvolvimento individual de empresas e grupos, como no capitalismo ocidental. As redes ou clãs relacionam-se entre si potencializando os recursos disponíveis para financiar os empreendimentos comerciais. Segundo Chuang, estas redes estão por tás das atuais empresas privadas que atuam na China e são um dos sustentáculos do altíssimo índice de produtividade do país (CUNHA; MELLO, 2005) ${ }^{24}$

Alguns chineses se mudaram para o Rio de Janeiro ou voltaram para China, o que resultou na saída dos acordos. Vale mencionar que houveram conflitos devido alguns chineses terem vendido produtos abaixo da tabela acordada entre eles.

\footnotetext{
${ }^{24}$ Disponívelem:http://lemetro5.blogspot.com.br/2005/08/saara-reinventandoetnicidades-e.html. Acesso em: 05 de novembro de 2017.
} 
Desse modo, as compras diretamente com empresários na China ficaram comprometidas, o que pôs fim no comércio de produtos Made in China das lojas 1,99 em São Gonçalo. Após essa crise, muitos chineses fecharam esse tipo de comércio, famoso em atrair brasileiros interessados em produtos baratos. Como modo para sair da crise, os chineses optaram em abrir lanchonetes, livres de acordos coletivos e por já dominarem as técnicas de elaboração dos alimentos. Essas lanchonetes passaram ser chamada popularmente de "pastelarias". Posso não ter como trabalhar. Não se fica sem trabalhar. Fazer esses salgados da vitrine já se aprende na China e aqui apenas mudamos para que vocês comam do jeito que gostam (Quon, filho de chineses, 26 anos). As pastelarias chinesas, facilmente caíram no gosto da população gonçalense e multiplicaram-se em vários bairros da cidade, todavia, com forte concentração no Alcântara, Centro e bairros adjacentes.

Em nossas conversas questionei sobre as experiências de Quon em ter morado no Paraguai, Brasil e China e, quais eram as impressões que ele tinha de viver em São Gonçalo. De acordo com Quon, ele gostava de viver na capital do Paraguai por se identificar com o lugar devido à concentração de chineses e taiwaneses. De acordo com ele, não haviam diferenças em serem chineses e taiwaneses, todos se identificavam como membros pertencentes ao mesmo grupo por compartilharem a mesma língua e cultura. Quando questionei sobre divergências, sobre conflitos entre chineses e taiwaneses devido aos conflitos históricos e políticos que envolvem a China e Taiwan ${ }^{25}$, Quon respondeu:

25 "Sob o ponto de vista étnico, especialmente de ancestralidade, Taiwan é basicamente chinesa. A população atual é composta por $2 \%$ de aborígenes, $84 \%$ de "taiwaneses" (hakkas e fukiens) e 14\% de mainlanders. Os chamados "taiwaneses" são aqueles que chegaram à ilha no século XVII, graças ao comércio marítimo, sendo oriundos do sudeste chinês (hakkas da província de Guangdong e fukiens, província do continente de frente para ilha" (PINHEIROMACHADO, 2010, p. 472). 
Há conversas sobre quem seria mais chinês e qual seria a real China. Mesmo com as brigas e guerras entre as duas [China e Taiwan], nós somos a mesma coisa e sabemos disso. Eu nunca tive problemas com isso [sic]. No Paraguai, os chineses e taiwaneses são mais parecidos do que com paraguaios e até brasileiros. (Quon, filho de chineses, 26 anos).

Ele relatou que na escola que estudou aprendeu guarani e espanhol, entre os intervalos das aulas conversava em mandarim devido à presença significante de chineses e taiwaneses. Quon ainda relatou que no Paraguai sua família não se sentia vigiada por outros chineses. No Paraguai não tinha chineses que ficam nos olhando para dentro da lanchonete como é aqui. Aqui há sempre comentários [de outros chineses] sobre com quem estamos conversando e 'andando' [amizades] (Quon, filho de chineses, 26 anos).

Baseado em Barth (2000), ao observar as fronteiras étnicas dos chineses foi possível constatar a condução da vida social através da organização social complexa nas sociabilidades e comportamental. "A identificação de uma outra pessoa como membro de um mesmo grupo étnico implica um compartilhamento de critérios de avaliação e de julgamento (BARTH, 2000, p. 34). Ele comentou que no Paraguai os pais tinham mais autonomia devido à língua. Mesmo para os pais, que falavam poucas palavras em guarani e espanhol, era possível receber ajuda de outros chineses em solucionar dificuldades cotidianas através da tradução, como ir ao supermercado, irem a consultas médicas e resolver problemas diários $^{26}$. Eles se relacionavam com chineses e por isso não houve a necessidade de aprender as línguas locais. Já as crianças estudavam em escolas paraguaias, que resultou no aprendizado no guarani e espanhol.

\footnotetext{
${ }^{26}$ Quon relatou que quando os pais viveram no Paraguai não falavam guarani e espanhol. Quando se mudaram para o Brasil precisaram aprender português por não terem ajuda de outros chineses.
} 
$|60|$

Uma etnografia da comunidade chinesa...

No Paraguai havia mais cooperação entre os chineses e até com os taiwaneses. Um ajudava o outro, entendeu? Não havia a vigilância que tem por aqui. Aqui os chineses não ajudam quando é preciso algo em português ou mesmo em emprestar algum alimento para fazer comida. Toda vez que passa um chinês na frente da loja de outro, olha bem lá dentro. Se ele e achar que está fazendo algo errado começa a falar com os outros. Sempre a controle de tudo! É sobre com que conversa, como está vestido, o que tem em sua loja... (Quon, filho de chineses, 26 anos).

No Brasil, ele se sente observado a cada momento e isso o deixa incomodado. Ele disse que o fenótipo da etnia han ${ }^{27}$ é uma marca por onde esteja, pois outro chinês observará o que está fazendo. Minha aparência de chinês diz muito sobre quem sou para outros chineses. Podemos ser chineses nascidos em qualquer lugar do mundo, mas sabemos que de alguma maneira somos da China devido ao nosso rosto chinês (Quon, filho de chineses, 26 anos). Ele disse que por ter aparência de chinês da etnia han, é identificado e observado por chineses sobre suas atitudes nos cidades da região metropolitana nos quais tem vínculos sociais: São Gonçalo, Niterói, Rio de Janeiro, Nova Iguaçu e Duque de Caxias. No Brasil há um chinês observando outro. No Paraguai e na China são assim, mas aqui o controle sobre outro é maior (Quons, filho de chineses, 26 anos). Ele relatou que os chineses buscam ser referência para serem seguidas por outros nas comunidades em que estão estabelecidos pela região metropolitana do Rio de Janeiro. Na cidade de São Gonçalo, os chineses acabam sendo observados sobre suas atitudes e como estabelecem vínculos com brasileiros. Durante as conversas que tive com Quon no Shopping Patarge e na lanchonete da família

${ }^{27}$ A população da China é estimada em 1.376.048.943 habitantes (708.977.116 homens; 667.071.827 mulheres) (IBGE, 2017). Em sua composição populacional é de 56 etnias reconhecidas pelo Partido Comunista Chinês. A etnia han representa $92 \%$ da população, as demais etnias são consideradas minorias (PEN, 2001). Todos os chineses que foram entrevistados e observados na etnografia dessa pesquisa são da etnia han. 
dele, nós éramos observados por outros chineses que passavam próximo de nós. Quando estávamos juntos conversando pude perceber que era constantemente vigiado por outros chineses.

Quon relatou que no período que viveu na China sob os cuidados dos avós maternos se sentiu observado, não se considerou que era julgado por outros chineses. Eu gostei de morar na China, até penso em voltar viver por um tempo. [...] Na China eu não era vigiado a cada momento pelos outros chineses (Quon, filho de chineses, 26 anos). Ele disse que nos três anos que viveu na China aperfeiçoou-se na fala em mandarim e cantonês, aprendeu a escrita dos caracteres chineses. No Brasil faz curso de mandarim para aprender a escrever melhor. Quon e a maioria dos chineses da diáspora chinesa que vivem no Leste Metropolitano têm como língua materna o cantonês e o mandarim como segunda língua. Os chineses adquirem outra língua na sociedade em que se estabelecem e, no caso dos jovens, passam a ter o primeiro contato nas instituições de ensino.

Quon relatou que gostava de morar em São Gonçalo, contudo, ficava cansado com trabalho que desempenhava na lanchonete da família e pela dependência que os pais têm por ele e pelos irmãos por não conseguirem se expressar em português ${ }^{28}$ $\mathrm{O}$ depoente relatou que se vivessem no Paraguai e não falassem as línguas oficiais, os pais seriam menos dependentes dos filhos. Em Ciudad [del Este] meus pais teriam ajuda de chineses que falassem espanhol. Haveria ajuda por não haver competição e fofocas como se tem aqui (Quon, filho de chineses, 26 anos). Quon gosta de viver em São Gonçalo e estar inserido em redes de chineses na cidade, todavia, a presença da comunidade sínica no cotidiano deixa-o incomodado.

\footnotetext{
${ }^{28}$ Ao longo da etnografia observei a presença de crianças e adolescentes pelos estabelecimentos. Eles estudavam na maior parte do tempo e ajudava os adultos em atividades quando eram solicitadas. Percebi que haviam crianças próximos aos adultos que não tinham domínio da língua portuguesa para conversar com funcionários e clientes brasileiros.
} 


\subsection{Estranho participante interno}

Como pesquisador, passei a sentir a necessidade de participar ainda mais do cotidiano daquela família chinesa que trabalhava na lanchonete e compreender seus movimentos migratórios. Por causa da minha presença constante que foi naturalizada e aceita pela família de Quon e principalmente, devido à sua amizade, minha presença atrás do balcão da lanchonete foi aceita. Nesse momento pude conhecer com intimidade as dinâmicas relacionais dos chineses e o caderno de campo não foi usado para que as escritas das observações não causassem estranheza à parte da família e até mesmo dos clientes. Como pesquisador, me familiarizei com a cultura dos chineses em São Gonçalo por querer participar do cotidiano deles e compreender suas redes sociais ${ }^{29}$.

No intuito de facilitar minha presença e poder me inserir no cotidiano, me prontifiquei a exercer atividades de trabalho sem remuneração com interesse de aproximar dos chineses. Eles aceitaram que eu pudesse trabalhar na lanchonete sem remuneração por compreenderem de maneira errônea que eu estava lá para praticar a conversação em mandarim. Eu acabei responsável por lavar as louças nos dias que estivesse presente na lanchonete. Não apenas lavei as louças como limpei o chão e fritava os salgados sempre sob a supervisão de algum chinês da família, que não fazia nada nos momentos em que eu estava trabalhando. Eu era sobrecarregado a lavar as constantes louças sujas e também o chão da cozinha enquanto o irmão mais velho de Quon, Mêncio, responsável por essas atividades, não as realizava.

De acordo com os pais deles, Mêncio estava estudando para processo seletivo do vestibular no qual queria cursar Engenharia Elétrica na Universidade Federal do Rio de Janeiro (UFRJ). Nos períodos de pouco movimentodeclientesnalanchonete, deitávamos sobre os sacos trigo juntos com os outros chineses e descansava.

${ }^{29}$ De acordo com Roberto DaMata: “[...] de fato, quando o etnólogo consegue se familiarizar com uma cultura diferente de sua, ele adquire competência nesta cultura [...]" (DAMATA, 1978, p. 27). 
Às vezes nós deitávamos em uma grande esteira que era colocada no chão da cozinha e até dormíamos. Nesses momentos percebi que os chineses usavam seus celulares para conversar com outros nacionais que viviam na Região Metropolitana do Rio de Janeiro, São Paulo, Paraguai e da China através do aplicativo WeChat ${ }^{30}$.

As tentativas de aproximação e conversa com a mãe de Quon, que se chama Xanadu, e com seu pai, chamado de Yan, eram recusadas com justificativas que estavam ocupados. Durante minhas pesquisas de campo em 2012 e 2013 percebi que os chineses têm hábitos constantes de fumar cigarro e com o casal não era diferente. Notei que eles fumavam a cada intervalo de uma hora e quando havia poucos clientes na lanchonete eles fumavam juntos na saída dos fundos. Observei a marca do cigarro que eles fumavam e na semana seguinte levei um maço e quando eles foram fumar, aproveitei para ir fumar com eles ${ }^{31}$

Em minhas tentativas para conversar com eles através do cigarro foram frustrantes, pois eles ficavam em silêncio. Optei conversar em mandarim na tentativa de ser assimilado e ter inserção nas conversas entre eles. Xanadu, disse em português que minha pronuncia não era boa, todavia, eu sabia falar. Você é ruim para falar chinês, né! (Xanadu, chinesa, aproximadamente 55 anos). Ela disse que eu precisava aprender falar mandarim de maneira correta e que poderia melhorar durante o tempo. Eu disse que faria isso e quando fosse para China tentaria aperfeiçoar. Eles ficaram animados pelo meu interesse em estudar a China. Nesse

\footnotetext{
${ }^{30}$ Aplicativo para celular criado na China, é utilizado pelos chineses para se comunicarem e transferir dinheiro. Durante a pesquisa soube que o WeChat é um meio importante para realizar acordos de trabalhos e compras de mercadorias chinesas. Em minhas observações, percebi que os chineses em São Gonçalo estão conectados diretamente com seus familiares na China. Como pesquisador, instalei esse aplicativo em meu celular e percebi que esse aplicativo georreferencia usuários que estão próximos. Eu notei que haviam muitos brasileiros e principalmente chineses em São Gonçalo e em outros municípios em que estive.

${ }^{31} \mathrm{O}$ pesquisador não fuma.
} 
dia nossa conversa foi curta e voltamos ao interior da lanchonete para trabalharmos.

Na semana seguinte quando voltei para trabalhar, continuei com a tática de estar com eles nos intervalos para fumar. Logo que o intervalo iniciou, fui direto para porta dos fundos e já ofereci os cigarros que estavam em meu bolso ${ }^{32}$ Eles aceitaram meus cigarros, pois eu sabia através das minhas vivências com chineses que quando se oferece cigarro para um homem e ele recusa é entendido como falta de educação. Esse costume é mais comum no campo e quando um homem oferece cigarro a outro é uma maneira de iniciar um diálogo. Eu continuei nossa conversa através de uma pergunta: "Como é a China?" Yan ${ }^{33}$ disse que era bonita e gostava de visitar a família. Já Xanadu, disse que a China é bonita e que uma parte dela ainda estava por lá. Eu disse que estudo a imigração chinesa para São Gonçalo e gostaria de entender os motivos dos chineses de viverem no Brasil. E questionei: "Por qual motivo vocês vieram para São Gonçalo?".

Nossa vinda para aqui foi necessidade. E não vontade, né! Não tínhamos trabalho e naquele tempo difícil. Irmos para Shangai para trabalhar e ter vida melhor. Eu e ele não tínhamos vida, não ganhávamos para pagar uma casa. Por causa da carta [hukou] não nos deixava. (Xanadu, aproximadamente 55 anos, chinesa).

No dia seguinte quando estava na cozinha com Xanadu e Quon questionei sobre o que ela achava da China e do Brasil. Ela disse que quer voltar para China para ser enterrada após a morte, mas prefere viver no Brasil em face das dificuldades serem menores.

32 Bronislaw Malinowski em sua etnografia nas Ilhas Trobriand relata "Trocamos alguns comprimentos em inglês pidgin, dei-lhes um pouco de tabaco - e assim criou-se entre nós uma atmosfera de mútua cordialidade" (MALINOWSKI, 1978, p. 19)

${ }^{33}$ Ele costuma ser calado e não conversa muito com familiares e outras pessoas. 
Eu gosto da China e quero ir para passar minha morte. Não quero viver como vivi em Shangai e não pode ter educação para meus filhos ou saúde. Sem carta não é fácil. Viver daquele jeito é difícil. Aqui posso ter minhas coisas mesmo e tá bom. Gosto daqui e não é fácil viver por aqui (Xanadu, aproximadamente 55 anos, chinesa).

A vontade de Yan e Xanadu de se fixarem em São Gonçalo se manifesta maior do que o desejo de regressar e viver na China. De acordo com eles, há possibilidades de voltarem ao Paraguai caso seja vantajoso, por terem contatos já estabelecidos, contudo, pensam na região metropolitana do Rio de Janeiro devido aos estudos dos filhos. Desse modo, eles não têm interesse em retornar à China e converterem os registros domiciliares através do suborno. Desse modo verificamos que: "Os chineses, por sua vez, estão em um movimento migratório distinto, marcado pela mobilidade, pela transitoriedade e pela circulação constantes, o que altera enormemente sua perspectiva de integração à cultura local" (CUNHA; MELLO, 2005 $5^{34}$ ).

A despeito dos esforços, não conseguia estabelecer contato mais profundo e muitas vezes fui totalmente ignorado. Certo dia, Quon a pedido dos pais, me pediu que não retornasse à lanchonete por estar os incomodando com minhas perguntas. Na tentativa de reverter aquela decisão que impedia minha continuação no campo, simplesmente tive o silêncio como resposta. Acreditei que seria melhor não insistir com receio de sofrer alguma possível retaliação por partes de Yan e Xanadu em minhas aproximações dos chineses ao longo da pesquisa.

\section{Conclusão}

Esta pesquisa buscou compreender e analisar os movimentos migratórios em redes de imigração chinesa na cidade de São

\footnotetext{
${ }^{34}$ Disponível em:http://lemetro5.blogspot.com.br/2005/08/saara-reinventandoetnicidadese.html. Acesso em: 05 de novembro de 2017.
} 
Gonçalo. Parti da premissa inicial de redes atreladas às migrações, acreditando que os deslocamentos migratórios, mesmo os de sujeitos aparentemente isolados, constituem uma imensa rede em que circulam pessoas, informações e dinheiro, de modo formal ou informal. Ao longo do texto foi demonstrado que um dos principais motivos para os chineses migrarem para São Gonçalo na Região Metropolitana Fluminense é a constituição de redes com chineses já estabelecidos nas cidades de Duque de Caxias, Nova Iguaçu, Rio de Janeiro e São Gonçalo. No decorrer da pesquisa, foi observado que a imigração chinesa em São Gonçalo está baseada nas redes migratórias e comerciais espalhadas pela região metropolitana do Rio de Janeiro. Para pensar a imigração chinesa em São Gonçalo é preciso analisar as diversas escalas e perceber como esses imigrantes estão interligados em redes migratórias e comerciais.

Através da etnografia foi possível descobrir que os chineses recém-chegados possuem vínculos comerciais e de familiaridade com aqueles já estabelecidos há mais tempo na cidade de Nova Iguaçu eesse vínculo funcionou como incentivo para que eles fossem recepcionados, acolhidos e ajudados no momento de chegada ao Brasil. Os imigrantes chineses observados e/ou entrevistados durante a pesquisa declaram que seu objetivo ao imigrar para o Brasil é trabalhar para juntar dinheiro, buscando uma condição de vida melhor na China. No decorrer da pesquisa, foi observado que a maior parte dos imigrantes chineses estabelecidos na cidade de São Gonçalo são oriundos de cidades do interior das províncias de Guangdong e Fujian e migram para grandes centros urbanos com objetivo de trabalharem em serviços de baixa qualificação e enviar dinheiro para os familiares que vivem no interior. De acordo com eles, viver nos centros urbanos não garante direitos trabalhistas e constantemente são alvos de batidas policiais por não terem autorização residencial do hukou para viver nos centros urbanos. Conseguir autorização pelo Partido Comunista para troca do hukou rural para urbano é difícil devido às poucas autorizações concedidas pelo Partido. A maneira encontrada pelos chineses para conseguir alterar seus registros de residência é através de altas quantias de suborno aos funcionários do governo. A dificuldade de 
reunir dinheiro trabalhando em empregos com baixa remuneração em fábricas impulsionam chineses a imigrarem para outros países através das redes migratórias já estabelecidas.

A imigração chinesa para o Brasil é impulsionada pela facilidade de ingressar em território nacional apenas com Visto de Visita, diferente de outros países - Estados Unidos, Austrália, Reino Unido e Espanha, por exemplo, que possuem restrições e maiores controles. Além disso, os chineses podem permanecer em território nacional após a expiração do visto de turista, posteriormente regularizando a situação no País através do nascimento de filhos em solo brasileiro ou casando com descendentes de imigrantes chineses. Através da etnografia foi percebido o interesse em querer ter filhos nascido no Brasil como garantia de direitos aos pais. $\mathrm{Na}$ região metropolitana do Rio de Janeiro, os chineses imigraram primeiramente para Nova Iguaçu, Duque de Caxias ou Rio de Janeiro por terem familiares e amigos que os convidam para trabalharem e em seus comércios com a promessa que poderão reunir a quantia necessária para voltar à China e trocar o hukou. Em alguns casos, os acordos de trabalhos acabam não sendo cumpridos, o que muitas vezes resulta na mudança para outras cidades.

Além disso, a atuação da Polícia federal é mais assídua nessas cidades e o receio de sofrerem possíveis deportações, por estarem com vistos de estadia no Brasil já vencidos e realizando atividades não condizentes com autorização de permanência como estrangeiro no país, contribuem para sua migração para São Gonçalo. Os chineses migram para São Gonçalo por já terem familiares e amigos estabelecidos que podem ajudá-los em questões burocráticas como abrirem lojas e lanchonetes. A cidade de São Gonçalo acaba sendo atrativo para que possam se estabelecer devido à fraca atuação da Polícia Federal e também pelo forte comércio que contempla cidades do Leste Metropolitano. Por fim, é importante destacar que o estudo da imigração chinesa para o Brasil ainda é um tema pouco estudado, que o material aqui reunido é apenas a ponta de um iceberg e uma primeira pesquisa prospectiva, que fornecerá material para vários desdobramentos e aprofundamentos do trabalho inicial. 


\section{Referências}

ARAÚJO, M. S. “Chineses no Rio de Janeiro: Notas sobre nação, território e identidade através da prática comercial e religiosa". In: Cadernos do CEOM. Chapecó, volume 23, número 32, 2010, pp. 221-240. Disponível em: <https://bell.unochapeco.edu.br/revistas/ index.php/rcc/article/view/674>. Acesso em: 04 de novembro de 2017.

BARTH, F. “Os grupos étnicos e suas fronteiras". In: O guru e o iniciador e outras variações antropológicas. Rio de Janeiro: Contra Capa, 2000.

CUNHA, N. V. da; MELLO, P. P. T. de. Saara: Reinventando etnicidades e ambiências urbanas num mercado popular carioca. 2010. Disponível em: <http://lemetro5.blogspot.com.br/2005/08/ saara-reinventando-etnicidades-e.html $>$. Acesso em: 04 de novembro de 2017.

DAMATA, R. “O ofício do etnólogo ou como ter anthropological blues". In: NUNES, E. O. (org.). A aventura sociológica: Objetividade, paixão, improviso e método na pesquisa social. Rio de Janeiro: Zahar, 1978, pp. 23-35.

FOOTE-WHITE, W. Sociedade de Esquina: Estrutura social de uma área urbana pobre e degradada. Rio de Janeiro: Zahar, 2005.

GEERTZ, C. A interpretação das culturas. Rio de Janeiro: LTC, 2008 .

MALINOWSKI, B. K. Argonautas do Pacífico ocidental: Um relato do empreendimento e da aventura dos nativos nos arquipélagos da Nova Guiné melanésia / Bronislaw Malinowski; Prefácio de Sir James George Frazer; Traduções de Anton P. Carr e Lígia Aparecida Cardieri Mendonça; Revisão de Eunice Durhan. - 2 ed, São Paulo: Abril Cultural, 1978. 
PEN, L. "Patologías prevalentes em pacientes de etnia china". In: MEDIFAM. Madrid, volume 11, número 07-Julio 2001. Disponível em:<http://scielo.isciii.es/pdf/medif/v11n7/hablemosde.pdf $>$. Acesso em: 27 de novembro de 2017.

PINHEIRO-MACHADO, R. Made in China: Produção e circulação de mercadorias no circuito China-Paraguai-Brasil. Tese (Doutorado em Antropologia Social), Porto Alegre: Universidade Federal do Rio Grande do Sul, 2009. Disponível em: <http://www. lume.ufrgs.br/handle/10183/16895>. Acesso em: 15 de março de 2016.

SILVA, M. de. A. Guanxi nos trópicos: Um estudo sobre a diáspora chinesa em Pernambuco. Tese (Doutorado em Antropologia Social), Recife: Universidade Federal de Pernambuco, Recife, 2008. Disponível em: <http://repositorio.ufpe.br/handle/123456789/445>. Acesso em: 05 de novembro de 2017.

TREVISAN. C. Os chineses. São Paulo: Contexto, 2014.

VELHO, G. “Observando o familiar". In: NUNES, E. O. (org.). A aventura sociológica: Objetividade, paixão, improviso e método na pesquisa social. Rio de Janeiro: Zahar, 1978, pp. 36-46.

WOLF, E. R. "Etnicidade e nacionalidade". In: FELDMANBIANCO, B.; RIBEIRO, G. L. (orgs.). Antropologia e Poder. Brasília / Campinas: Editora da UnB / Editora da UNICAMP, 2003. 
